\title{
Introduction:
}

\section{The Case for Inclusive Voting Practices}

\begin{abstract}
The voter turnout gap has plagued many elections around the world, with differential levels of participation between groups having the potential to effect election results and policy outcomes. Despite this, there has been little empirical or normative theorisation of the interventions that can be used redress the turnout gap and other inequalities within the electoral process. This article defines the concept of inclusive voting practices to refer to policy instruments which can reduce turnout inequality between groups and mitigate other inequalities within the electoral process. This is anchored in a strategic-relational theory of structure, agency and political change. Different state responses are conceptualised and the normative case for an interventionist rather than repressive or laissez-faire approaches is set out. A research agenda is set out which is taken up in subsequent articles in this special issue.
\end{abstract}

Professor Toby S. James

School of Politics, Language and Communication Studies, University of East Anglia, Norwich, UK.

\section{Dr. Holly Ann Garnett}

Royal Military College of Canada in Kingston, Ontario, Canada.

This is an author accepted version of a paper accepted for publication in Policy Studies. Please cite that final version. 


\section{Introduction}

Writing in 1960, Schattschneider (1960, 98-111) noted how only approximately 60 out of 100 million eligible voters in America cast their ballot. Considering the possible effects of universal turnout he suggested that:

'The whole balance of power in the political system could be overturned by a massive invasion of the political system... the unused political potential is sufficient to blow the United States off the face of the earth' (p.98).

Fast forward into the twenty-first century and the consequences of voter turnout - or non-turnout are felt in the US and in other countries around the world. Whether it is the US Presidential election, landmark referendums such as the UK Brexit referendum, or the contest for the Nigerian Presidency: voting matters. The effects of the ballots cast at the polls have decisive impacts on national politics, public policy and even the broader international system. However, the votes that are not cast make a profound difference too. Turnout levels are often low, uneven and the results of many elections may have been different with fuller participation. This has a renewed importance in established democracies where new electoral cleavages have arisen. It is commonly thought, for example, that these cleavages are based around age (Norris and Inglehart 2018), but since young people are much less likely to vote, electoral outcomes are less likely to be in their favour. Meanwhile, variations in turnout has a continued importance in electoral autocracies which are struggling to make the full transition to liberal democracy because, amongst other reasons, turnout is reduced by threats of electoral violence, keeping autocrats in power.

Voter turnout is affected by many factors, but the machinery of the electoral process plays a crucial role. America has a long history of the political elite using racially-based discriminatory practices to deter citizens from voting (James 2012). The passage of the 1965 Voting Rights Act was designed to eliminate this, but concerns remain today as restrictive voter ID requirements have been rolled out across many states (Hasen 2012). The US experience, however, is too infrequently situated into broader international experience. Threats to inclusive voting practices are emerging elsewhere, as the UK and Canada have introduced, and revised their voter identification requirements. In Africa, biometric technologies have required citizens to have their fingerprints taken before registering and voting. Poor provisions for overseas voters have prevented diaspora populations from voting in central America and elsewhere. Violence against voters remains a fundamental problem which deters many groups from going to the polls. 
The academic literature in this area remains underdeveloped. Democratic theory rightly preaches that elections should be 'free and fair' (Dahl 1971), but rarely makes reference to the importance of inclusive and convenient polling practices. There are 'best practices' in the international community (Carter Center 2014), which argue for inclusive procedures, but these remain unconnected to political theory. Work by political scientists in the US on American democracy does not necessarily capture the nature of the threats in other parts of the world, or propose workable solutions to them. A broader reconceptualization of the concept of 'inclusive voting procedures' is required to unify these literatures and enable a global approach to promoting fuller turnout.

This introduction to the special issue on inclusive voting practices will begin by considering the nature of group-level inequality in voter turnout worldwide. It will then review existing work on how institutional procedures can shape voter turnout. Next, it will define the concept of inclusive voting processes through a strategic-relational approach. Different state responses to voting inequality are considered and the case for an interventionalist approach is laid out. Finally, the special issue ahead is briefly summarised, which takes on the agenda for considering inclusive voting practices.

\section{The Global Turnout Gap}

Literature on voter turnout has long demonstrated that the characteristics of people who turn out to vote, and the characteristics of those who stay away are not the same. Some of the most important socio-demographic variables considered in this literature include age, income, education, gender, ethnicity and disability, as well as attitudinal variables such as political interest (Smets and van Ham 2013). It is important to note, however, that much of this literature rests on study of established democracies.

First, studies have broadly demonstrated that voter turnout increases from youth to middle age, and then experiences a slight decline for the oldest age groups. The reasons for lower voter turnout among the youngest voters stem from a variety of factors including lower levels of political interest, civic duty, social pressure, and the perceived importance of voting (Jankowski and Strate 1995; Smets and van Ham 2013; Strate et al. 1989). Literature on voter turnout has also suggested a slight decline in turnout among seniors, possibly due to health issues or difficulties in getting to the polls (Cutler and Bengtson 1974; Norris 2002; Smets and van Ham 2013). These studies suggest that turnout levels among groups of voters, and perhaps even generations of voters, are rarely equal.

The socioeconomic model of voter turnout (Brady, Verba, and Schlozman 1982; Verba and Nie 1972) posits that an individual's social status, including type of job, level of education, and income, is an important predictor of voter turnout. These studies suggest that education influences a variety of factors that directly influence the choice of whether to vote or not, including civic skills, political 
attitudes and feelings of efficacy, and the social networks that instil a duty to vote (Burden 2009; Emler and Frazer 1999). It is worth mentioning that the scholarly community is increasingly sceptical of the argument that education actually causes higher voter turnout, with some arguing that education level serves as a proxy for other factors relating to social status, family background and other early life influences (Burden 2009; Kam and Palmer 2008; Persson 2013). Nonetheless, the relationship between education and turnout has been demonstrated both in the American context and crossnationally, though it is important to note that some scholars have found that the predictive power of education is lower, or even non-significant, in some Western European countries (Gallego 2010; Norris 2002).

The relationship between gender and voter turnout has also been well-studied. Firstly, lower levels of turnout among women may, unsurprisingly, exist in places where women's civil rights are less secure (Desposato and Norrander 2009). Additionally, some research has also suggested that gaps in political knowledge and interest between men and women may also relate to unequal levels of turnout (Carpini and Keeter 1996; Lizotte and Sidman 2009; Mondak and Anderson 2004; Verba, Burns, and Schlozman 1997). These gaps in turnout could be due to a number of reasons, including differential educational attainment, the availability of time to devote to amassing political knowledge, or gendered patterns of employment.

Voters from ethnic minorities have also been demonstrated to have lower levels of turnout than other voters. A variety of reasons for this phenomenon have been studied. Most scholars acknowledge some potential influence of lower socio-economic status among some minority voting groups. Other studies focus on structural barriers to voting, suggesting that lower turnout among minorities may be related to voter suppression, or cases of electoral laws that unfairly disadvantage minority groups (Hajnal, Lajevardi, and Nielson 2017). Other research suggests it is more of a matter of mobilization or empowerment (Banducci, Donovan, and Karp 2004). In the American context, for example, Fraga (2018) finds that ethnic and racial minorities turn out to vote at lower rates largely because they are not mobilized to be engaged with politics.

Finally, research has demonstrated a sizable turnout gap between citizens with and without disabilities. Research from the United States, for example, has suggested about a 20-point turnout gap between those with and without disabilities (Schur et al. 2002). This may be related to a variety of reasons: including polling place accessibility and lower registration rates (Schur 2013; Schur, Ameri, and Adya 2017). Additionally, citizens with disabilities may have lower levels of social capital (Schur et al. 2002), a phenomenon also found for populations with low levels of health (Mattila et al. 2013). These voters may also not be part of the networks that would encourage them to vote, characterized by higher levels of income and education. Finally, citizens with disabilities may have a lower sense of 
efficacy to participate in politics, especially if they are not part of the aforementioned social networks that encourage civic engagement.

According to psychological models of voting, political interest is key to explaining whether a voter will turn out or not (Blais 2000). Citizens with higher levels of political interest will pay more attention to politics and election campaigns. Importantly, that interest may translate into greater political knowledge, which may decrease the information costs of voting, such as forming political preferences, researching candidates and determining where and when to vote (Carpini and Keeter 1996; Popkin and Dimock 1998; Zaller 1990).

To demonstrate the significance of the variables mentioned above, Table 1 presents a multilevel logistic regression model of the predictors of an individual's responses that they 'vote always,' with data from the $6^{\text {th }}$ wave of the World Value Survey. Unfortunately, disability and being a member of an ethnic or racial minority are difficult to measure at a cross-national level and are therefore not included in the analysis. It also includes two important control variables related to the electoral laws in a country: whether voting is compulsory and the type of electoral system (Blais and Aarts 2006; Blais and Carty 1990; Blais and Dobrzynska 1998). The results support the previous discussion regarding the relationship between gender, age, education, income and political interest and voter turnout. 
Table 1: Predictors of "Vote Always"

(1)

"Vote Always"

Female

$-0.04 * *$

(0.02)

Age (linear)

$0.03^{* * *}$

(0.00)

High School Education

$0.14^{* * *}$

(0.02)

Post-Secondary Education

Income Steps

$0.01^{* * *}$

$(0.00)$

Interested in Politics

$0.58^{* * *}$

(0.02)

Compulsory Voting

$1.11^{* * *}$

(0.26)

Mixed Electoral System

0.26

(0.29)

Proportional Representation Electoral System

0.22

(0.25)

Constant

Rho

0.16

(0.03)

N (Individuals)

77,813

$\mathrm{N}$ (Countries)

55

Multi-level models. Standard errors in parentheses $* * * p<0.01,{ }^{* *} p<0.05,{ }^{*} p<0.1$.

See Appendix A for more details about data.

In sum, there exist clear turnout gaps based on a variety of individual characteristics, from age and gender to disability and health. The question now remains: how can these gaps be closed? 


\section{Existing work on Inclusive Voting Practices}

Inclusive voting practices are defined in this article as policy instruments which reduce inequality in the electoral process for citizens, including, but not limited to the voter turnout and registration gap. ${ }^{1}$ There are many other aspects of the electoral process which can do this, such as the electoral system design. Here, we focus how citizens to register to vote and cast their ballot.

The idea that voting processes can affect turnout, inclusivity, and by extension, democratic outcomes, is not new. It has been conceptually underdeveloped, however, and remains absent in many definitions or discussions of democracy and electoral integrity. The traditional pillars of democratic theory were silent on the issue, for example. Minimalist approaches to defining democracy, such as those set out by Robert Dahl (1971) and Adam Przeworski (1999) identify many features of elections that are prerequisites for a state to be defined as democratic - but these include little about how voting takes place other than that it should be done in secret. In contrast, substantive theorists define democracy as the realisation of certain principles. For David Beetham (1994), for example, this is political equality and popular control of government - but there is no detailed mapping of the electoral institutions that can help to realise this.

Detailed policies for realizing this goal of equal turnout is more prevalent amongst the international community. The third wave of democratisation and globalisation led to the development of global networks of international actors who sought to define standards for how elections should be run, which were sketched into international treaties, political agreements, interpretative documents and other sources (Carothers 2003; James 2020). Such agreements have been consolidated into assessment manuals so that they can be used by observers to evaluate elections. As the Carter Center (2014) manual details, this includes a commitment to a variety of practices that seek to ensure inclusively and political equality. To take one example, the United Nations Convention on the Rights of Persons with Disabilities, adopted in December 2006, calls on states to:

'ensure that persons with disabilities can effectively and fully participate in political and public life on an equal basis with others, directly or through freely chosen representatives, including

\footnotetext{
${ }^{1}$ We should of course also be mindful of other forms on inequality in the electoral process. For example, if citizens are given an unequal experience at the polling stations because of their ethnicity, age or geographical location then this too violates the principal of inequality. An inclusive voting practice would seek to address this too, even though it was not directly related to turnout.
} 
the right and opportunity for persons with disabilities to vote and be elected (United Nations 2007, 21).'

These agreements are landmark moments towards the realisation of inclusive voting practices. In fact, these statements are often taken as the definition of electoral integrity itself (Norris 2013). They remain unconnected to political theory, however. Allowing political actors to define what inclusive practices work removes the role of the academic research to assess, refine and change 'best practices'.

Modern political science largely overlooked electoral practices as an area of study, instead focussing on voter behaviour and the effects of electoral system, until Wolfinger and Rosenstone's seminal (1980) work responding to the question Who Votes?. They produced some of the early empirical work on why voting practices can make a difference. Over time, many more studies followed. These were mostly based on evidence from the US, many triggered by the politics of the National Voter Registration Act (for a review see, James 2012). Studies gradually have expanded to other established democracies, however (see, for example: Bochsler 2010; Garnett 2019a, 2019b; Germann and Serdült 2017; James 2011). Outside of Western democracies, work has been less frequently published with exceptions including Virendrakumar et al. (2018), who charted the (non) availability of inclusive practices for disabled voters in Africa.

Additionally, existing research has for the most part been framed within a rational choice (institutionalist) framework, but this has been a subject of criticism. Wolfinger and Rosenstone explicitly started with a rational choice conception when they explained that "...we find it useful to think in terms of the benefits and costs of voting to the individual... The easier it is for a person to cast a ballot, the more likely he is to vote," (Wolfinger and Rosenstone 1980, 6-8). Rational choice theory has been much criticised, however (Aldrich 1993). Given the marginal difference that a single vote can have - voting is an entirely irrational act anyway. It is therefore important to understand the cultural and normative context in which voting takes place. As Galicki $(2018,41)$ argues, "voting can be viewed as an act of belonging or acceptance of the "system"'". She therefore sets out sociological institutionalism as an alternative approach. This includes a focus on the wider set of informal norms and the cultural context in which individuals vote - rather than the just the formal-legal institutions and how they structure incentives.

There has been some work to conceptualise different types of practices to promote equal turnout. For example, James uses the concepts of expansive and restrictive forms of electoral administration according to whether they increased or lowered turnout in a meta-analysis of earlier studies, and places procedures onto an 11 point ordinal continuum (James 2010). Similarly, Pallister uses the term election administration inclusiveness to refer to "the degree to which the administration 
of the electoral process facilitates or hinders the ability of eligible citizens to vote" (Pallister 2017, 3). Procedures were then ranked on a three-point scale.

Other work has considered the political and policy consequences of inclusive voting practices. Do they favour the parties or candidates from an ideological position? What are the policy consequences? Are some procedures, for example, capable of redressing the severe economic inequalities that are present in most societies? Some scholarship has sought to use the questions to argue that electoral practices have consequences for the theorisation of the state. Theories of the state are meta theories about the nature of the state, it's relationship with citizens and in whose interests it serves (Dunleavy and O'Leary 1987). The liberal democratic model of the state saw it as a neutral arbiter between competing interests. Elite theory instead argued that the state can be shaped by the incumbents to suit its own interests. James therefore argued that governing elites would be tempted to choose voting procedures that maximised their chances of winning seats. Meanwhile, in their earlier writing, Piven and Cloward (1983) claimed that the battle for inclusive voting procedures involved attempts to redress racial and class struggles.

There have been several advances, but there are also notable gaps. It seems to be widely recognised that normative theory is important for justifying elections as a method of rule, but says nothing about the details of how elections should be run. There is evidence that voting and registration procedures matter, but they tend to draw on empirical studies of the US. There are some theoretical works conceptualising the causal effects on institutions and citizens, but these are not always developed in full.

What are the basic requirements for underlying theory? First, it must include both the effects of calculus as suggested by rational choice theorists and the role of cultural context set out by sociological institutionalists. It is not an either/or. Individuals are more likely to vote when it is more convenient for them to do so - but cultural context should matter as well (Peters 2005).

Second, it requires a theory of causation that is sensitive to context. The same voting practices in one country may have different meanings in different setting. It might not be possible to neatly transport and implant a policy from one jurisdiction to another.

Thirdly, it must acknowledge that knowledge about the likely effects of reforms among the agents of practices can cause counter-effects. The introduction of voter identification requirements might, ceteris paribus, cause voting levels to decline because some voters will not have access to the required ID. However, a counter-mobilisation against 'voter suppression' may indirectly cause voter ID to have a positive effect on turnout. The lines of causality are therefore complex. 


\section{A Strategic-Relational Framework}

The effect that voting practices might have on voters can be conceived through a structure and agency relationship. There is a rich scholarship from the social sciences on the relationship between structure and agency (for example, see: Hay 2002, 89-134). Agents are the political actors under study - in this case voters at an aggregate and individual level. Structure refers to the contextual factors that might shape the behaviour of the actors. There are a variety of perspectives, ranging from an intentionalist position that emphasises the freedom of the individual to act without constraint, to the polar opposite structuralist position in which individuals are simply the bearers of their social context. An intepretivist approach provides the exemplar of the former approach in which individual are given autonomy to act within their beliefs (Bevir and Rhodes 2002; Bevir 2010). Conversely, and paradoxically, rational choice theory gives agents no autonomy - they are assumed to be driven by a logic of calculated interests which are shaped by their contextual environment (Hay 2002, 103-4).

The strategic relational approach to structure and agency that is used in this article was developed by Bob Jessop $(2001,2005)$. This has not been used to conceptualise the relationship between the citizen and electoral institutions until to now, since the common position is to use rational choice theory. The strategic relational approach, however, has been used in other areas of study on political institutions such as the study of prime ministers (Byrne and Theakston 2018; James 2018a).

This approach conceptualises agents as strategic actors who are capable of free-thinking. However, they are situated within a strategically selective environment which might shape their preferences, incentives and beliefs. It involves studying how agents might find themselves in situations that might 'privilege some actors, some identities, some strategies, some spatial and temporal horizons, some actions over others; and the ways, if any, in which actors (individual and/or collective) take account of this differentiated privileging... when choosing a course of action' (Jessop $2001,1224)$. Strategically selective environments therefore do not determine outcomes because agents are reflexive actors capable of strategic learning.

Importantly, the approach begins from a critical realist ontological and epistemological position conceptualises the world as having a stratified social reality. There are therefore many deep structural causes which might not be immediately observable to the researcher using purely behaviouralist techniques. These structures often include gender or class-based politics. In the field of elections, this sensitises us to how individuals might be more subtly persuaded to vote or not vote. It is also important to note that this approach is often linked to a realist conception of knowledge. Rather than seeing the world as an object that can be studied in a hermetically sealed environment, 
the accumulated knowledge about the world is shared with it. As a result, those under study can change their strategic behaviour, armed with this knowledge (James 2020; James 2018b). For example, one research finding might be that voter identification requirements lead to lower levels of turnout amongst some groups. The documentation and dissemination of this knowledge to political parties, activists and voters, however, might change their future behaviour.

Causation is therefore context specific. The use of quantitative methods can help to identify how institutions have shaped behaviour in the past, but it is no guarantee that these causal effects will reoccur in the future. Actor have the ability for strategic learning from past experiences. Meanwhile, the same institutional practices may have different effects in different situations where cultural meanings and practices are different (James 2020, 27-8; Pawson 2006, 21).

The strategic-relational approach has been applied to few empirical avenues of research, so the structures that might affect the agents under study have not yet been sketched out. We therefore set out the following propositions about those which will shape individual behaviour:

- Most obviously, electoral laws and institutions will shape whether individuals vote by providing the institutional environment. At the most obvious level, legal enfranchisement is a pre-requisite for participation. Requirements to provide different forms of identification, for example, will affect the calculus of whether to vote by making it more burdensome.

- The technical, managerial and financial resources available to electoral officials will matter too. A lack of polling staff might mean that queues will develop which could discourage voters. Poor or faulty equipment, lack of accessibility features for disabled voters, or reduced funding for voter outreach activities could be the result of financial austerity policies (James and Jervier 2017). Policy instruments such as voter registration reforms can have 'back-office' effects on the running of elections, such as increased costs (James 2020).

- Cultural practices might also be exclusionary. The act of casting a vote is not a robotic act but one which takes place in locations with embedded social meanings (Bertrand, Briquet, and Pels 2007; Coleman 2013; Orr 2016). But such cultural practices and meanings are never neutral - they can have exclusionary dynamics. Rituals and norms can shape expectations about the 'proper' role of individuals. It might become 'normalised', for example, for women to vote as instructed by men in polling stations as part of a set of patriarchal power relations.

- Strategic action of others will be important. In a world of necessity, actors will take strategic action to coerce or shape the behaviour of others. In the context of elections, these tactics might involve campaigning behaviour around the poll which are intimidating or threatening, 
or might explicitly threaten or undertake violence against others in order to win an election (Birch and Muchlinski 2018).

- Informational resources about how to register to vote and cast a ballot can shape whether citizens participate on Election Day. The state may not, for example, provide clear websites detailing the process (Garnett 2017). There can also be concerted disinformation campaigns by parties and other agents to deter some blocs of voters from participating, by claiming that polling stations are closed, voting hours are different to what they are or falsely suggesting voter identification requirements are needed ( $\mathrm{Pal} 2017)$.

- More deeply rooted educational resources, meanwhile, provide citizens with knowledge about citizenship and how they can be active in the political system. These could be widely distributed, held by a minority, or widely absent in a political system.

The generative mechanisms therefore include both culture and calculus, transcending the traditional institutionalist accounts of human behaviour (Peters 1999).

A strategically selective environment will shape individual behaviour, but the environment can also be shaped over time by the actors situated within it. As Jessop remarks, actors:

'orient their strategies and tactics in the light of their understanding of the current conjuncture and their "feel for the game"' (Jessop 2001, 1224)

It in the context of elections, citizens, activists and parties might seek to alter the laws and cultural practices through which elections are run to generate a new strategically selective environment. There is therefore an interactive relationship with agents that can change structures through advocacy, as figure 1 illustrates. 

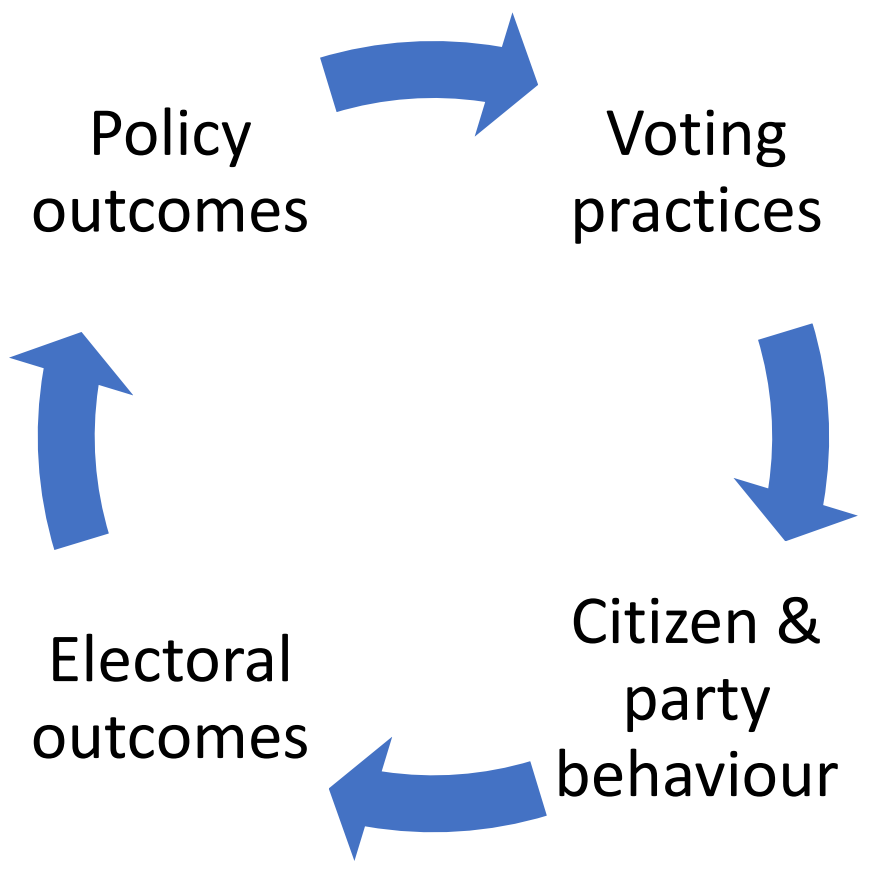

Figure 1: The cyclical relationship between voting practices, elections and reform.

\section{State Response: Electoral Policy and Machinery}

If there is a strategically selective environment in which there are uneven levels of turnout amongst groups, how could the state respond? We categorise state responses to the challenge of ensuring inclusive elections:

- Repressive. Rulers will often to shape the apparatus of the state in order to maximise their electoral interests. This might involve deliberate attempts at voter intimidation, instructions to stuff ballot boxes, or placing polling stations in areas far away from the voter. Repressive policies are therefore deliberate and partisan attempts to restrict the participation of particular groups with view to gaining political advantage. This is not limited to autocracies. Governing elites may instead seek to deploy strategies to supress voter turnout amongst key groups through policies such as onerous voter identification requirements etc.

- Laissez-faire. Political inequality does not always come about through such active repression. In fact, elections could be nominally 'free and fair' by international standards and the criteria set out by minimalist democratic theorists such as Robert Dahl, but the outcomes of the electoral process could be marked by high levels of political inequality. This is because the 
state might, borrowing language from economic policy, take a minimalist, laissez-faire approach to running elections where the most basic polling provisions are provided. Elections are hypothetically implemented to a high standard in so far as the rules, however the onus has been left to the individual to educate themselves, register and vote. Typical policies might include the absence of proactive efforts to tackle underlying uneven levels of voter education or turnout. Responsibility to register to vote might lie with the citizen.

- Interventionist. Lastly, an interventionist approach is where the state is proactive at identifying cultural and material inequalities in voting practices in a given socio-political context and develops policies to address these. These policies will be context-specific to the nature of the problem. However, they might include proactive or automatic registration systems, election violence mitigation or social media regulation.

\section{The case for inclusive voting procedures}

If there is a strategically selective environment in which there are uneven levels of turnout amongst groups, how should the state respond?

As the review above makes clear, there has rarely been a detailed, explicit link between the study of voting procedures and normative political theory. An important decision has to be made for how to define democracy. There are, of course, a variety of different ways of doing this. One common approach is to take a minimalist approach in which a polity can be considered 'democratic' if we are able to witness the presence of certain institutional arrangements. Robert Dahl's Polyarchy provides the classic exemplar of such an approach (Dahl 1971). Robert Dahl claimed that democracy was characterised by the 'continuing responsiveness of the government to the preferences of its citizens, considered as equal weights' (Dahl 1971, 1). Unpacking this, Dahl thought that there were eight institutional guarantees that would be needed for a polity to be considered a polyarchy, the ideal system of government. These included the 'right to vote', 'free and fair elections' and 'freedom of expression' (ibid p.3).

Meanwhile substantive normative theorists criticised the idea of evaluating institutions according to whether they match a pre-determined list of procedures. David Beetham, for example, argued that doing so provides no rationale for why these institutions should be considered 'democratic' (Beetham 1994, 26). Most worryingly, basing assessments on a pre-defined list offers no way of considering how that list could be improved over time (Beetham 1994, 26-7). He therefore encourages us to evaluate democratic institutions by the outcomes that they produce. In particular, 
a polity can be considered democratic where it realises the goals of political equality and popular control of government.

While these approaches have many differences, one theme that it is common to theme both is political equality remains central. The world may (or may not) involve varying levels of social and economic equality, but democratic institutions should neither privilege or disadvantage any citizen. They should be 'considered as an equal weight' as Dahl claims or 'collectively considered as equal's as Beetham suggests.

Repressive electoral procedures, as sketched out above, would clearly be a violation of these normative goals. It is also the case that laissez-faire policies, however, are insufficient for realising the ideals of political equality in a democracy. If citizens are in strategically selective environments in which their propensity to vote is affected by factors outside of their control, then realising political equality requires intervention. If there is electoral violence then the state response cannot be laissezfaire - intervention is required to ensure that everyone is able to vote without intimidation. If there are lower levels of electoral registration amongst young people then interventions are required to address to bring balance. If voters with disabilities are less likely to vote because the polling stations are designed for those without disabilities, then interventions are required.

In the sphere of economic policy, laissez-faire policies have often been grounded with a moral rationale. The role of government should be minimal to create free market conditions, in which businesses and entrepreneurs can prosper, generate profit and economic wealth. The argument of monetarists and free-marketeers is that mutual benefit is gained as wealth 'trickles down'. But there is no mutual gain in electoral integrity or democratic politics with state non-intervention. Those who benefit are the parties, candidates and voters who are already winners; those who lose are those who do not participate. Democratic states must therefore seek out and implement interventionist, inclusive voting practices.

A further critical argument of intervention is that voting is an individual responsibility and the state should not play a proactive role in shaping individual behaviour. These arguments are intuitively compatible with liberal democracy, which sprang from a defence of the rights of the individual. The absence of inclusive voting practices in a strategically selective environment, however, immediately sees the power and equality of many individuals and groups being undermined. Without such interventions, individuals might find themselves with formal voting rights, but situated within a legal, cultural, administrative, informational and educational environment in which they are unequal to their peers and much more unlikely to vote than a peer. Moreover, group inequality can be generated from the absence of inclusive voting practices. Societies are not collections of identical individuals. Social 
patterns, class structures, political cleavages emerge which brings divergences amongst groups interests. Allowing a turnout gap, without intervention is therefore a direct breach of the principles of democracy.

\section{Special Issue Ahead}

This introductory article has set out the concept of inclusive voting practices and given it a normative grounding. What constitutes an inclusive voting practice, however, is partially contextually specific because it depends on the level of turnout inequality between groups in a given scenario and how different policy instruments interact in different spatial-temporal environments. This special issue therefore pushes open a new research agenda to consider: ${ }^{2}$

- What are the different causal pathways for causing exclusion at the ballot box? Who tends to be excluded or negatively affected by voting processes?

- Which electoral processes are effective at ensuring inclusion? Which are not? What proactive state action and regulation is required?

- Beyond introducing political equality, what are the wider effects of inclusive voting practices?

- Given their importance, when and why are such policies instruments not undertaken by the state?

Subsequent articles take the agenda forward, beginning with Victoria Shineman who focusses attention on how many would-be electors are excluded from the franchise. The move towards becoming a full democracy involved the franchise being extended to women, non-property owners and all ethnicities, but some groups remain legally unable to vote. Felons are amongst many groups in democracies who are acutely affected by the outcome of elections but who in some jurisdictions have their right to vote removed because of their prior criminal record. Shineman considers the effects of restoring voting rights to felons on their attitudes and behaviors, using experimental treatments to help make the normative case for inclusive voting practices.

Eric Guntermann, Ruth Dassonneville and Peter Miller look at the effects of compulsory voting. This is potentially one of the most important inclusive procedures because in theory it eradicates inequalities in turnout by ensuring everyone votes, thereby reducing the difference between rich and

\footnotetext{
2 Papers were primarily drawn from leading academics and policy makers from the pre-APSA workshop on 'Building Better Elections: New Challenges in Electoral Management', held at MIT in Boston in 2018, convened by the editors.
} 
poor. They consider whether this then also has effects on the nature of representation within legislatures.

Paige Schneider and David Carroll consider the problem of electoral violence. Violence and perceived threats of violence are an obvious impediment for citizens voting. Although there has been considerable literature on the topic, the authors argue that the gendered nature of electoral violence needs to be built into any future research on the topic and has so far been overlooked. They illustrate this using their ethnographic fieldwork in Uganda.

Voter ID requirements have often been at the heart of contemporary political debate about voting practices. They have been incited to be modern 'Jim Crow laws' because they reduce turn out amongst some groups, more than others. Anthony Kimball and David C. Kimball look at the implementation of photo ID implementation in Missouri. Meanwhile, Toby S. James and Alistair Clark consider the uneven experiences of voters in English local elections. The effects of the introduction of a set of voter ID pilots, the first ever in British elections is then charted.

Citizens are often left in long lines to wait to cast their vote. Bridgett King identifies how these wait times and other administrative irregularities are experienced differently across different groups in the American electorate. The effects of these problems on voter confidence in the electoral process are then mapped.

The experience of citizens with disabilities at considered by Powell and Johnson, who note how they are considerably less likely to vote. They assess the ways in which people with disabilities are disenfranchised by election administration barriers such as voter registration, voter identification regulation and methods of ballot submission, using survey data from the US.

Another community to be legally disenfranchised are non-resident citizens, who might wish to vote abroad. Kevin Pallister notes that many countries have reformed policies to enable them to vote. Pallister identifies the drivers for these reforms in the cases of El Salvador and Guatemala to help to identify generalisations about when and why moves to inclusive practices might occur.

The coverage of the articles is therefore geographically extensive and cover many voting practices. The articles collectively help to establish what practices constitute inclusive voting practices, what their effects are, and what the drivers might be. In the concluding article we draw out the lessons from the special issue as a whole for the study of democracy and electoral institutions. We think that a profound rethinking of the concept is needed so that it includes the provision of inclusive electoral practices. We also set out the policy lessons for the international community and governments 
worldwide, upon whom the burden lies to respond to the research and introduce inclusive electoral practices. 


\section{Appendix A: Variables and Data Sources for Table 1}

\begin{tabular}{|c|c|}
\hline Variable & Details \\
\hline \multicolumn{2}{|l|}{ Individual Level } \\
\hline Gender & $\begin{array}{l}0 \text { Male } \\
1 \text { Female }\end{array}$ \\
\hline Age & Continuous Variable (16-99) \\
\hline Education & $\begin{array}{l}\text { What is the highest educational level that you have attained? } \\
\text { 0. No formal education } \\
\text { 1. Incomplete primary school } \\
\text { 2. Complete primary school } \\
\text { 3. Incomplete secondary school: technical/vocational } \\
\text { 4. Complete secondary school: technical/vocational } \\
\text { 5. Incomplete secondary school: university preparatory } \\
\text { 6. Complete secondary school: university- preparatory } \\
\text { 7. Some university-level education, without completion } \\
\text { 8. University - level education, with degree } \\
\text { Reduced to three categories: } \\
\text { 0. Did not complete, or less than secondary education (reference) } \\
\text { 1. Completed secondary education } \\
\text { 2. Some or completed university-level education }\end{array}$ \\
\hline Income & $\begin{array}{l}\text { On this card is an income scale on which } 1 \text { indicates the lowest income group } \\
\text { and } 10 \text { the highest income group in your country. We would like to know in } \\
\text { what group your household is. Please, specify the appropriate number, } \\
\text { counting all wages, salaries, pensions and other incomes that come in. } \\
\text { 0. Lower step } \\
\text { 1. Second step } \\
\text {... etc. } \\
\text { 9. Tenth step }\end{array}$ \\
\hline Voting & $\begin{array}{l}\text { 'When elections take place, do you vote always, usually or never?: National } \\
\text { level } \\
\text { 1. Always } \\
\text { 2. Usually } \\
\text { 3. Never } \\
\text { Reduced to two categories: } \\
\text { 0. Usually or never (combined since there is often a bias towards stating that } \\
\text { one usually votes) } \\
\text { 1. Always }\end{array}$ \\
\hline Political Interest & $\begin{array}{l}\text { How interested would you say you are in politics? } \\
\text { 0. Very interested } \\
\text { 1. Somewhat interested } \\
\text { 2. Not very interested } \\
\text { 3. Not at all interested } \\
\text { Reduced to two categories: } \\
\text { 0. Not at all or not very interested. } \\
\text { 1. Somewhat or very interested }\end{array}$ \\
\hline \multicolumn{2}{|l|}{ Country-Level } \\
\hline Compulsory Voting & $\begin{array}{l}0 . \text { Not compulsory } \\
\text { 1. Compulsory }\end{array}$ \\
\hline Electoral System & $\begin{array}{l}0 \text { Plurality/Majoritarian } \\
1 \text { Mixed } \\
2 \text { Proportional Representation } \\
\text { (Categorical variable with plurality/majoritarian as reference category) }\end{array}$ \\
\hline
\end{tabular}




\section{Datasets}

- WORLD VALUES SURVEY Wave 6 2010-2014 OFFICIAL AGGREGATE v.20150418. For more details, see: http://www.worldvaluessurvey.org/wvs.jsp

- International IDEA. Data \& Tools. https://www.idea.int/data-tools

Countries Included:

- Taiwan

- Georgia

- Palestine

- Germany

- Japan

- Libya

- Mexico

- New Zealand

- Pakistan

- Philippines

- Russia

- Zimbabwe

- Thailand

- Ukraine

- Azerbaijan

- Australia

- Bahrain

- Belarus

- Ghana

- India

- Kuwait

- Malaysia

- Nigeria

- Singapore

- Trinidad and Tobago

- Egypt

- United States

- Uzbekistan
- Yemen

- Algeria

- Argentina

- Armenia

- Brazil

- Chile

- Colombia

- Cyprus

- Estonia

- Iraq

- Kazakhstan

- Jordan

- Kyrgyzstan

- Lebanon

- Morocco

- Netherlands

- Peru

- Poland

- Romania

- Rwanda

- Slovenia

- South Africa

- Spain

- Sweden

- Tunisia

- Turkey

- Uruguay

Data from 55 countries where relevant questions were asked in the World Values Survey, $6^{\text {th }}$ Wave (2010-2014) 
Bibliography

Aldrich, John H. 1993. "Rational Choice and Turnout." American Journal of Political Science, 37, (1), p. 246-78.

Banducci, Susan A., Todd Donovan, and Jeffrey A. Karp. 2004. "Minority Representation, Empowerment, and Participation." The Journal of Politics, 66, (2), p. 534-56.

Beetham, David. 1994. "Key Principles and Indicies for a Democratic Audit." In Defining Democracy, edited by David Beetham. London: Sage.

Bertrand, Romain, Jean-Louis Briquet, and Peter Pels. 2007. Cultures of Voting: The Hidden History of the Secret Ballot. London: C. Hurst \& Co.

Bevir, M., and R.A.W. Rhodes. 2002. "Interpretive Theory." In Theory and Methods in Political Science, edited by D.Marsh \& G.Stoker. London: Palgrave.

Bevir, Mark. 2010. Democratic Governance: Princeton University Press.

Birch, Sarah, and David Muchlinski. 2018. "Electoral Violence: patterns and trends." In Electoral Integrity and Political Regimes: Actors, Strategies and Consequences, edited by Holly Ann Garnett and Margarita Zavadskaya, 100-12. Abingdon and New York: Routledge.

Blais, André. 2000. To Vote or Not to Vote? : The Merits and Limits of Rational Choice Theory. Pittsburgh: University of Pittsburgh Press.

Blais, André, and Kees Aarts. 2006. "Electoral Systems and Turnout." Acta Politica, 41, (2), p. 180-96.

Blais, AndrÉ, and R. K. Carty. 1990. "Does proportional representation foster voter turnout?". European Journal of Political Research, 18, (2), p. 167-81.

Blais, AndrÉ, and Agnieszka Dobrzynska. 1998. "Turnout in Electoral Democracies." European Journal of Political Research, 33, (2), p. 239-61.

Bochsler, Daniel. 2010. "Can Internet voting increase political participation." In Paper presented at the Internet and Voting, Fiesole.

Brady, Henry E., Sidney Verba, and Kay Kehman Schlozman. 1982. "Beyond SES: A Resource Model of Participation." American Political Science Review, 89, (2), p. 271-4.

Burden, Barry. 2009. "The Dynamic Effects of Education on Voter Turnout." Electoral Studies, 28, (4), p. 540-9.

Byrne, Christopher, and Kevin Theakston. 2018. "Understanding the power of the prime minister: structure and agency in models of prime ministerial power." BRITISH POLITICS, p.

Carothers, Thomas. 2003. Aiding Democracy Abroad. Washington D.C.: Brookings Institution Press.

Carpini, Michael X. Delli, and Scott Keeter. 1996. What Americans Know about Politics and Why it Matters. New Haven: Yale University Press.

Carter Center. 2014. Election Observations and Standards: a Carter Centre Assessment Manual. Atlanta, Georgia: Carter Center.

Coleman, Stephen. 2013. How voters feel: Cambridge University Press.

Cutler, Neal E., and Vern L. Bengtson. 1974. "Age and Political Alienation: Maturation, Generation and Period Effects." The ANNALS of the American Academy of Political and Social Science, 415, (1), p. 160-75.

Dahl, R. 1971. Polyarchy: Participation and Opposition. New Haven: Yale University Press.

Desposato, Scott, and Barbara Norrander. 2009. "The Gender Gap in Latin America: Contextual and Individual Influences on Gender and Political Participation." British Journal of Political Science, 39, (1), p. 141-62.

Dunleavy, P. , and B. O'Leary. 1987. Theories of the State: The Politics of Liberal Democracy Basingstoke: Macmillan.

Emler, Nicholas, and Elizabeth Frazer. 1999. "Politics: The Education Effect." Oxford Review of Education, 25, (1/2), p. 251-73. 
Fraga, Bernard L. 2018. The Turnout Gap: Race, Ethnicity, and Political Inequality in a Diversifying America. Cambridge: Cambridge University Press.

Galicki, Celestyna. 2018. "Barriers to voting and the cost of voting among low socioeconomic, young and migrant voters in New Zealand." Political Science, 70, (1), p. 41-57.

Gallego, Aina. 2010. "Understanding Unequal Turnout: Education and Voting in Comparative Perspective." Electoral Studies, 29, (2), p. 239-48.

Garnett, Holly Ann. 2017. "Open election management bodies." In Election Watchdogs, edited by Pippa Norris and Alessandro Nai. New York: Oxford University Press.

-- . 2019a. "Early Voting: Comparing Canada, Finland, Germany, and Switzerland." Election Law Journal: Rules, Politics, and Policy, 18, (2), p. 116-31.

- - . 2019b. "Evaluating Online Registration: The Canadian Case." Election Law Journal: Rules, Politics, and Policy, 18, (1), p. 78-92.

Germann, Micha, and Uwe Serdült. 2017. "Internet voting and turnout: Evidence from Switzerland." Electoral Studies, 47, p. 1-12.

Hajnal, Zoltan, Nazita Lajevardi, and Lindsay Nielson. 2017. "Voter identification laws and the suppression of minority votes." The Journal of Politics, 79, (2), p. 363-79.

Hasen, Richard L. 2012. The voting wars: From Florida 2000 to the next election meltdown. Grand Rapids, MI: Yale University Press.

Hay, C. 2002. Political Analysis. Basingstoke: Palgrave Macmillan.

James, Toby S. 2010. "Electoral Administration and Voter Turnout: Towards an International Public Policy Continuum." Representation, 45, (4), p. 369-89.

- - . 2011. "Fewer 'costs,' more votes? UK Innovations in Electoral Administration 2000-2007 and their effect on voter turnout." Election Law Journal, 10, (1), p. 37-52.

-- - 2012. Elite Statecraft and Election Administration: Bending the Rules of the Game. Basingstoke: Palgrave Macmillan.

- - . 2018a. "Political leadership as statecraft? Aligning theory with praxis in conversation with British party leaders." The British Journal of Politics and International Relations, 20, (3), p. 555-72.

- - . 2020. Comparative Electoral Management: Performance, Networks and Instruments. London and New York: Routledge.

James, Toby S., and Tyrone Jervier. 2017. "The cost of elections: the effects of public sector austerity on electoral integrity and voter engagement." Public Money \& Management, 37, (7), p. 4618.

James, Toby Samuel. 2018b. "The Higher Education Impact Agenda, Scientific Realism and Policy Change: the Case of Electoral Integrity in Britain." BRITISH POLITICS, 13, (3), p. 312-31.

Jankowski, Thomas B., and John M. Strate. 1995. "Modes of Participation Over the Adult Life Span." Political Behavior, 17, (1), p. 89-106.

Jessop, Bob. 2001. "Institutional re(turns) and the strategic - relational approach." Environment and Planning A, 33, p. 1213-35.

- - . 2005. "Critical Realism and the Strategic-Relational Approach." New Formations, 56, p. 4053.

Kam, Cindy D., and Carl L. Palmer. 2008. "Reconsidering the Effects of Education on Political Participation." The Journal of Politics, 70, (3), p. 612-31.

Lizotte, Mary-Kate, and Andrew H. Sidman. 2009. "Explaining the Gender Gap in Political Knowledge." Politics \& Gender, 5, p. 127-51.

Mattila, Mikko, Peter Söderlund, Hanna Wass, and Lauri Rapeli. 2013. "Healthy voting: The effect of self-reported health on turnout in 30 countries." Electoral Studies, 32, (4), p. 886-91.

Mondak, Jeffery J., and Mary R. Anderson. 2004. "The Knowledge Gap: A Reexamination of GenderBased Differences in Political Knowledge." The Journal of Politics, 66, (2), p. 492-512.

Norris, Pippa. 2002. Democratic Phoenix: Reinventing Political Activism. New York: Cambridge University Press. 
- - . 2013. "The new research agenda studying electoral integrity." Electoral Studies, 32, (4), p. 563-75.

Norris, Pippa, and Ronald Inglehart. 2018. Cultural Backlash: the Rise of Authoritarianism-Populism. New York: Cambridge University Press.

Orr, Graeme. 2016. Ritual and rhythm in electoral systems: A comparative legal account. Abingdon and New York: Routledge.

Pal, Michael. 2017. "Canadian Election Administration on Trial: 'Robocalls', Opitz and Disputed Elections in the Courts." King's Law Journal, 28, (2), p. 324-42.

Pallister, Kevin. 2017. Election Administration and the Politics of Voter Access: Routledge.

Pawson, Ray. 2006. Evidence-based policy. London: Sage.

Persson, Mikael. 2013. "Education and Political Participation." British Journal of Political Science, p. Peters, G. 1999. Institutional Theory in Political Science: The 'New Institutionalism' London: Pinter.

- - . 2005. Institutional Theory in Political Science: The 'New Institutionalism. Second Edition ed. London \& New York: Continuum.

Piven, F.F., and R.A. Cloward. 1983. "Towards a Class-Based Realignment of American Politics." Social Policy, 13, (3), p. 3-14.

Popkin, Samuel L., and Michael A. Dimock. 1998. "Political Knowledge and Citizen Competence." In Citizen Competence and Democratic Institutions, edited by Stephen L. Elkin and Karol Soltan. University Park: Penn State University Press.

Przeworski, Adam. 1999. "Minimalist Conception of Democracy: A Defence." In Democracy's Value, edited by lan Shapiro and Casiano Hacker-Cordon. Cambridge: Cambridge University Press. [Reprinted in Robert A. Dahl et al (eds) The Democracy Sourcebook].

Schattschneider, Elmer Eric. 1960. The Semi-Sovereign People: A Realist's view of Democracy in America. New York: Holt, Rhinehart \& Winston.

Schur, Lisa. 2013. Reducing Obstacles to Voting for People with Disabilities, Presidential Commission on Election Administration.

Schur, Lisa, Mason Ameri, and Meera Adya. 2017. "Disability, voter turnout, and polling place accessibility." Social Science Quarterly, 98, (5), p. 1374-90.

Schur, Lisa, Todd Shields, Douglas Kruse, and Kay Schriner. 2002. "Enabling Democracy: Disability and Voter Turnout." Political Research Quarterly, 55, (1), p. 167-90.

Smets, Kaat, and Carolien van Ham. 2013. "The Embarrassment of Riches? A Meta-analysis of Individual-level Research on Voter Turnout." Electoral Studies, 32, (2), p. 344-59.

Strate, John M., Charles J. Parrish, Charles D. Elder, and Coit Ford. 1989. "Life Span Civic Development and Voting Participation." American Political Science Review, 83, (2), p. 443-64.

United Nations. 2007. United Nations Convention on the Rights of Persons with Disabilities. New York: United Nations.

Verba, Sidney, Nancy Burns, and Kay Lehman Schlozman. 1997. "Knowing and Caring about Politics: Gender and Political Engagement." The Journal of Politics, 59, (4), p. 1051-72.

Verba, Sidney, and Norman H. Nie. 1972. Participation in America: Political Democracy and Social Equality. New York: Harper \& Row.

Virendrakumar, Bhavisha, Emma Jolley, Eric Badu, and Elena Schmidt. 2018. "Disability inclusive elections in Africa: a systematic review of published and unpublished literature." Disability \& Society, 33, (4), p. 509-38.

Wolfinger, Raymond E., and Steven J. Rosenstone. 1980. Who Votes? New Haven, CT: Yale University Press.

Zaller, John. 1990. "Political Awareness, Elite Opinion Leadership, and the Mass Survey Response." Social Cognition, 8, p. 125-53. 